\title{
From good to eat to good to watch: whale watching, adaptation and change in Icelandic fishing communities
}

\author{
Níels Einarsson \\ Stefansson Arctic Institute and the University of Akureyri, Borgir, Nordurslod, IS-600 Akureyri, Iceland
}

\author{
Keywords \\ Arctic anthropology; human-environmental \\ relations; fishing; Iceland; whale watching. \\ Correspondence \\ Niels Einarsson, Stefansson Arctic Institute, \\ Borgir, Nordurslod, IS-600 Akureyri, Iceland. \\ E-mail: ne@svs.is \\ doi:10.1111/j.1751-8369.2008.00092.x
}

\begin{abstract}
Arctic and North Atlantic fishing communities may seem unlikely candidates for a viable whale-watching industry, because of the prevalent traditional consumptive attitudes towards marine mammals and their uses. The topic of this paper is the introduction of an internationally growing industry of whale watching in a fishing village in north-east Iceland, and how local inhabitants reconcile opposing views on whales, whaling and the new cetacean tourism. The paper also discusses the conflict between fishermen and marine mammals, and how it is managed in an area where fishing is still a mainstay of the economy, and where marine mammals are seen by many as competitors for scarce resources, and even as pests. This anthropological case study is used to address wider issues of adaptation, community viability and resilience in small resource-dependent coastal settlements, coping with rapid social and ecological change.
\end{abstract}

Since the early 20th century fishing has been the backbone of the Icelandic economy, and is still the most important industry in the country, in spite of the growing contributions of other sectors, such as aluminium production, financial services and tourism. In 2006, fishing and fish products provided $51 \%$ of all merchandise exports, down from close to $90 \%$ in the early 1960s. Cod continues to be the most valuable species in the Icelandic fisheries, accounting for about $36 \%$ of the total catch value (Central Bank of Iceland 2007: 24). With the cod stocks in poor condition, the Icelandic government followed the advice of the Marine Research Institute and reduced the cod quota by $30 \%$ for the fishing year of 2007-08 (1 September-31 August). This entails a drop in catches to 130000 tonnes from 190000 tonnes in the previous year. The Marine Research Institute recommends an even lower quota for the fishing year of 200809: 124000 tonnes. This decrease in the cod quota has had significant, and even dire, effects on businesses, communities and individual fishermen and fish workers, with a loss of income and employment opportunities, especially for those sectors and communities where cod has been the mainstay of the catch quota. Still, in spite of the importance of fishing for the national economy, people employed in fishing in 2005 numbered only around 3.5\% of the total workforce, whereas an additional $4.1 \%$ were employed in the fish processing industry (Central Bank of
Iceland 2007: appendix). Contemporary Icelanders enjoy a high standard of living and rank first in the 2007-08 United Nations Human Development Report Index.

Iceland is an island; however, to quote the editors of an anthropological compendium on Icelandic everyday lives and global contexts, "Culturally, politically and economically Iceland is not an island" (Durrenberger \& Pálsson 1996: 9). Few issues have made this fact clearer to Icelanders than the whaling issue that has centred on the policy in Iceland to continue harvesting whales, supported by the majority of the population, despite much opposition to such plans from abroad.

\section{Whaling and whale watching}

As early as 1990, a feasibility study on whale watching in Iceland sponsored by the International Fund for Animal Welfare (IFAW) concluded that organized cetacean watching in Icelandic waters was a real and viable possibility (Lindquist $\&$ Tryggvadóttir unpubl. ms.). The timing of the study was difficult, as the majority of Icelanders saw themselves in conflict with foreign environmental organizations over Icelandic whaling, which by 1990 had ceased as a result of an international whaling moratorium. The moratorium was the result of a decision made at the International Whaling Commission (IWC) meeting in 1982, and was to take effect in 1985-86. The parliament of 
Iceland, Alpingi, finally decided to abide by the IWC decision. Icelandic authorities did, however, continue with a programme of scientific whaling during 1986-89, but this policy came under attack from organizations such as Greenpeace, which organized boycotts of Icelandic fish products abroad with considerable success, as well as from more radical animal rights groups such as the Sea Shepherd Conservation Society, which was responsible for sinking/scuttling two whaling boats in Reykjavík harbour in 1988 (see Brydon 1990). The Icelandic government, supported by the overwhelming majority of the Icelandic public, took a hard-line attitude towards the interference of foreign organizations into what was seen as a test of Icelanders' sovereignty, and rights to use and manage the marine resources within the 200-mile exclusive economic zone. Apart from the nationalist discourse surrounding the whaling conflict, there was also a discussion about the nature and motives of environmentalists, who were commonly known in the vernacular as Grœnfridungar (Greenpeacers), a term that lumps together all those who were seen as anti-whaling in one category. This discourse was carried out at several levels of Icelandic society, but it was in the fishing villages that emotions ran highest. This was the segment of the population that felt most vulnerable, and at odds with foreign environmental ideologies and outside intervention (Einarsson 1990, 1993, 1996).

The whaling controversy is as much a clash of cultural assumptions about the relationship between humans and nature as it is about ecosystems, conservation biology and stock assessments. At the core of the whaling controversy lie fundamentally divergent perceptions and images of cetaceans, based on very dissimilar environmental experiences relating to these sea mammals. To understand the attitudes of Icelandic fishermen towards whales and whaling, as well as whale watching to some degree, we need to look at the everyday life of fishing, and how fisherfolk engage (to use Tim Ingold's terminology) with the environment in their pursuit of making a living (Ingold 2000). This practical engagement gives rise to a practitioner's point of view: a set of nature perceptions, ethno-ecologies and values that strongly influence the fisherfolk's responses to interactions with the sea mammals with which they share the marine ecosystem. The ban on whaling has contributed to the perception of growing whale populations as a problem, and even as a pest (in the vernacular meindýr, harmful animal), as whales are seen as consuming more than their fair share of the scarce fish stocks, in direct competition with fisherfolk and the fishing industry.

In the Icelandic context, whaling and whale products have more than symbolic value, as has been the case throughout the history of Icelanders since the island was settled in the 9th and 10th centuries. The word for windfall or godsend in Icelandic is hvalreki, literally, a stranded whale (Sigurjónsson 1989). The stranding of a whale was a stroke of extreme good luck, which could provide families and communities with large quantities of animal protein. Whale has previously been thought of as good to eat, although Icelanders today show little interest in consuming whale meat. However, the right to harvest whales remains at the core of the national fisheries policy, and indeed the rhetoric on the right to whale has recently moved from the right to hunt whale to the duty to do so, in the name of non-discriminatory sustainable use of natural resources, not excluding any animal species as less suitable for harvesting or consumption. This ethical dimension of duty is an interesting recent development, and constitutes a new facet to the existing discourse and an escalation of the stakes involved.

The predation of whales on commercially valuable and currently dwindling fish stocks is still a central question, and must be kept in mind when considering the social geography of ceteceans as pests and justifications for whale hunting. Icelandic authorities maintain that the annual consumption by whales of fish, krill and other prey is in the millions of tonnes, several times that of the total Icelandic fishery landings. The issue of the ecosystem impacts of cetaceans is a real one for a nation whose economy is, to a considerable extent, based on fishing.

The image and perception of whales in the Western world has changed fundamentally in the past decades, not least because of campaigns run by whale conservation bodies and environmental groups such as Greenpeace, World Wide Fund for Nature (WWF), IFAW and the Whale and Dolphin Conservation Society (WDCS). What many of these campaigns have had in common is the systematic anthropomorphizing or personification of cetaceans. Anthropomorphism and the projection of positive human qualities and motives onto cetaceans, and their behaviour, has been a key cognitive tool used by environmental groups dedicated to saving the whale. Whales thus endowed also became key symbols for the environmental movement. In the eyes and minds of the majority of Westerners, cetaceans no longer belong to the potential category of harvestable natural resources, and in a relatively short time there has been a total transformation in the public perception of whales (Einarsson 1993, 1997).

The enormous emotional and symbolic power of whale imagery was clearly demonstrated early in 2006, when a lost northern bottlenose dolphin found its way far up the English river Thames, and became, for a couple of days, the object of fascinating whale watching for Londoners, and for others around the world with access to Sky News and other major news channels. This individual cetacean managed to light up the existence of Londoners with its 
misguided journey, very much as its relatives did little more than a century ago in the age of British whaling, when whale oil was used as the primary fuel for the city's street lanterns. My intent is not to be sarcastic and sardonic, but simply to make a point about how fundamentally the image and ways of thinking about whales has changed. This perceptual transformation has also aided, and has possibly been fundamental to, the rise of whale watching throughout the world, including Iceland, and thus has become a resource in its own right. It is indeed the novel image and symbolic capital that whales embody that is being turned into a commodity in worldwide cetacean tourism, where people are given the opportunity to experience, sometimes in close encounters, these remarkable and enchanting creatures, which are also key symbols for the environmental movement.

Whale watching has become a booming worldwide industry that attracts around 10 million people a year who spend more than 1.25 billion US dollars. According to the WWF and whale-watching expert Erich Hoyt, the number of whale watchers is increasing by $12 \%$ a year, which is more than three times that of the overall tourism industry. There are 495 communities in 87 countries and territories that now offer whale-watching tours (see Wilson \& Wilson 2006; WWF 2008).

What happens when an industry that is based on people's modern interest in whales is brought into play in a country like Iceland, and especially in a sub-Arctic fishing community that is overwhelmingly pro-whaling, and where consumptive views of marine mammals are ingrained in the basic cultural assumptions and traditions? Some might believe that this is an unlikely social setting for a successful outcome of marine ecotourism with a focus on cetaceans. To explore the complexities and local institutional dynamics of this proposed problem, we can travel to a coastal community in northern Iceland.

\section{Húsavik: the whale-watching capital of Europe}

The village of Húsavík is located in the south-east part of the Bay of Skjálfandi, in north-east Iceland. The population numbered 2511 on 1 December 2006. Húsavík is one of oldest inhabited sites in Iceland, according to the Icelandic Book of Settlements. The main subsistence activity of the village has been fishing and fish processing, with herring catches and salting growing in importance in the early 20th century, and with the more recent development of demersal fishing for cod, haddock and other species, as well as shrimp. The shrimp fishery has, however, sharply declined in recent years, as a result of diminishing quotas. For centuries the town has been the centre of services for the neighbouring farming areas, and today it still includes industries connected to agriculture,

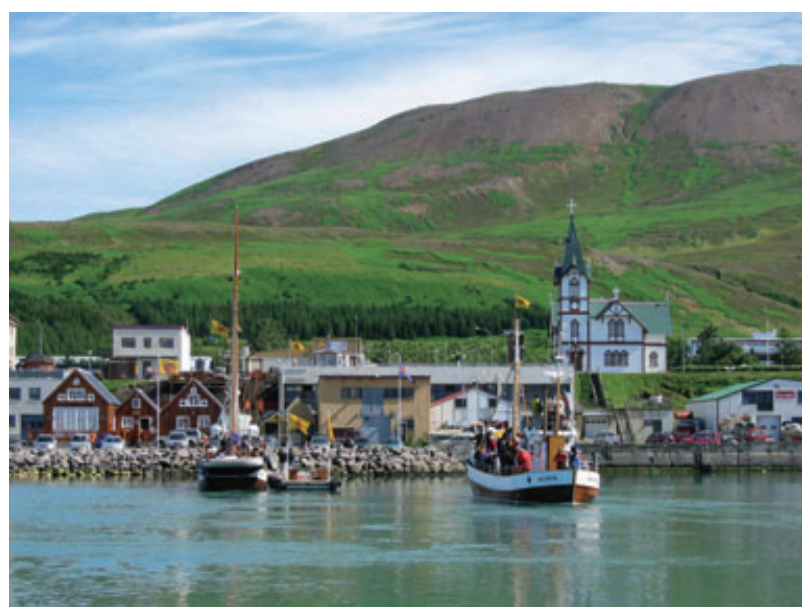

Fig. 1 Whale-watching boats in Húsavík harbour. (Photo by N. Einarsson.)

among them the largest slaughterhouse and meat-curing facilities in the north-east region of Iceland. Húsavík has a hospital, a college, several shops, a hotel and a number of other services to cater for the needs and wishes of a modern European population and its visitors. The policy of the town council has been to diversify the economy of the village, which has gone as far as to seriously consider, several years ago, to allow alligator farming in a geothermally heated waste-water pond close to the village. The preliminary plan was to feed the reptiles offal from the local slaughterhouse and fish processing industry. The plan never took off, as a permit for the import of alligators was not granted by the Icelandic veterinary authorities. More recently, in March 2006, the multinational corporation Alcoa announced its decision with the Icelandic government to investigate the feasibility of setting up an aluminium smelter, to be located a few kilometres north of Húsavík, and to be supplied with power from a geothermal electricity plant to be built at Peistareykir, about $15 \mathrm{~km}$ south of the town. If these plans materialize, and they seem to have popular support, then we can expect a major transformation of the social and economic landscape in the area of Húsavík, and neighbouring communities, in the years to come.

Nevertheless, it is whale-watching tourism that has brought most attention to Húsavík in the past decade (Fig. 1). Two companies currently offer whale-watching trips to Skjálfandi Bay from late April until October, although the whale-watching season has been getting longer as the number of tourists and the scale of operations have grown. In 2007 just over 40000 tourists were taken out to watch whales from the port of Húsavík, from a total of 104000 whale-watching tourists visiting Iceland. Húsavík is not the only place in Iceland to see whales and there are now six other locations, but in no 
other place has whale watching been such a success story. However, in recent years two companies in Reykjavík have gained momentum, and in 2007 half of all whale spotters went whale watching from Reykjavík.

Both Húsavík companies can be characterized as family owned and operated businesses, with the larger and more established one, Norðursigling (North Sailing), more visible in leading local development. In the summer of 2007 the companies had seven boats in operation, although one of two boats belonging to the smaller company, Hvalaferðir (in English called Gentle Giants, not a direct translation), was a modern, fast fibreglass boat used mainly for sports fishing and bird watching. Although smaller in scale and more recently founded, Hvalaferðir has firmer roots in the fishing culture of the community, with the owners having been active fishermen in Húsavík before turning to whale watching.

The boats used for whale watching are carefully restored former fishing and minke whaling boats, with hulls made of oak-on-oak frames. Built in Iceland in the 1960s and 1970s, these boats range from 15 to $23 \mathrm{~m}$ in length, and can carry between 45 and 84 passengers. The boats are of heavy displacement construction and are powered by relatively small diesel engines (considering modern standards), making them quite energy efficient. One of the boats has recently been fitted with schooner rig and sails. Such boats require a great deal of timeconsuming and expensive maintenance to keep up their appearances, but this is seen by the owners as well worth it. In my discussions with those who work in whale watching in Húsavík, the idea of these boats embodying souls of their own and symbolizing coastal culture has been mentioned many times. In fact, the original reason why the owners of the pioneering firm decided to invest in these rugged and authentic fishing boats was a passion for the boats themselves, and their restoration and salvage. They had no plans to use them for whale watching. That idea came up later, in the search for a worthy and viable role for the boats.

Traditional fishing boats became available at low prices partly as a consequence of the introduction of the contemporary Icelandic fisheries management system in 1984. The individual transferable quota (ITQ) system privatized the fisheries common property resources, and closed the formerly open-access fishing stocks in the exclusive economic zone (see Pálsson \& Helgason 1996). The transferability of quotas meant that smaller fishing operators sold out to bigger ones, or to those who saw advantages in increasing their own quotas. The economic rationale behind the new system was that more efficient units would buy out the less efficient ones, leading to an overall rationalization of the management system and economies of scale. The consequences of the system

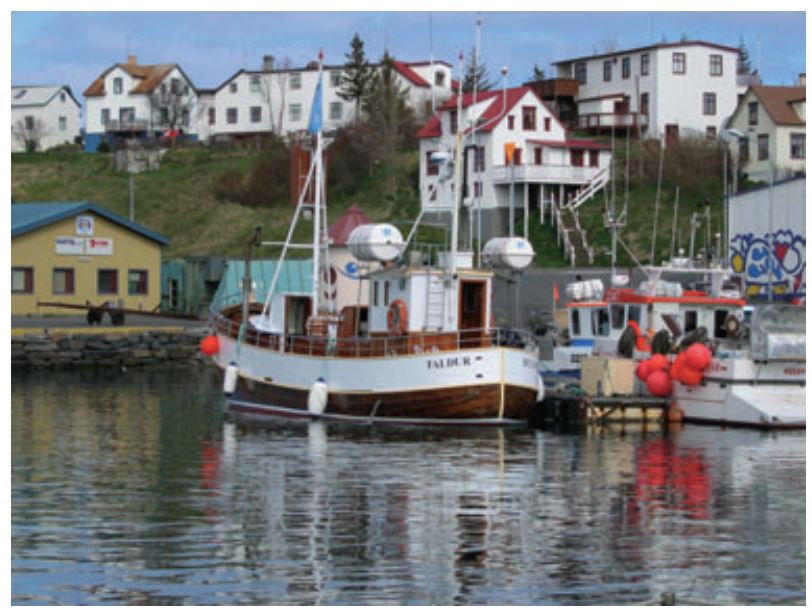

Fig. 2 Former whale-hunting boat, and a new fibreglass boat, used in whale watching. (Photo by N. Einarsson.)

have been manifold, one of them being that the total fish quota in Iceland has been accumulating in fewer hands, often away from the smaller fishing villages, and is now increasingly under the control of relatively few companies. In June 2007, 10 of the largest companies controlled $52 \%$ of the total quota holdings (Central Bank of Iceland 2007: 26). The externalities of the ITQ system thus made a large number of boats available, as the smaller and mostly owner-operated units were bought out of the system.

In the early days of the ITQ system, boat owners who sold their quota and left the system were eligible for grants if they stopped using their boats, but only if the boats were physically destroyed. For several years, boats often in perfectly good condition were therefore chainsawed and burned (such boats also provided suitable firewood for bonfire nights), so as to make their further use impossible. A heated debate and criticism of the so-called "boat bonfires" led to the abolition of the clause requiring boat destruction, and inexpensive boats then became available for uses such as catching tourists instead of fish (see Einarsson 1995; Fig. 2). This may have significantly contributed to making the early development of cetacean tourism economically feasible.

Another change in the economic and social structure of fishing villages occurred as the inhabitants were looking for new ways to sustain livelihoods and create jobs, especially after the ITQ system had made new recruitment to fishing increasingly difficult, as new fishing rights had to be bought on a market. Traditionally, anyone who could buy, beg, borrow or steal a boat could start out as a fisherman on nearby fishing grounds, and could even provide jobs for a family in land-based and labourintensive activities such as baiting longlines. With the 
introduction of the ITQs and the closure of the commons, and with sufficient capital not easily accessible, this became much harder.

Icelandic fishing villages have long shared the vulnerabilities and narrow economic base of other Northern resource-dependent settlements (see Caulfield 2004; Duhaime 2004). Economic diversification such as the development of tourism became more and more appealing to communities that were losing options, and were facing decreasing flexibility and increasing vulnerability as a consequence of changes in the regimes of resource governance. Whale watching can thus be seen as a form of adaptation, and a response to external drivers of change.

An updated estimate of a 2004 report on the significance of whale watching in Iceland gives a figure of 3.12 billion Icelandic crowns as the total revenue for the national economy, with 100000 whale watchers (Oddsson unpubl. ms.). However, estimating the economic importance of whale watching to the local community of Húsavík is not a straightforward task, and very few data are available. Still, 40000 tourists visiting such a small community, buying tickets to the whalewatching tours, using local services and visiting the museum do significantly strengthen the local economy. During the 2007 season, the two whale-watching companies had some 35-40 employees between them. In addition, there were between 12 and 14 people working in the Húsavík Whale Museum (see below). Although the whale-watching tours themselves are seasonal, the firms involved have staff doing maintenance and marketing all year round, especially in recent years, as the professionalism and numbers of visitors and operations have grown. The view of the regional Economic Development Office is that whale watching has considerable relevance for the economic viability of the community, not least for younger people who have the education and skills to participate in an internationally oriented enterprise that requires higher education levels and language skills. Few jobs of this kind have been available in the village, contributing to a drain of human capital from the community. That the new jobs have, to some extent, compensated for the jobs lost in the fishing and fish processing sector is also important.

It was in an atmosphere of decline that whale watching was started up in Húsavík in 1995, beginning with 2200 tourists that first summer, more than $90 \%$ of whom were foreigners, which continues to be the case. The new industry was welcomed by the local authorities and residents, who, in general, tend to have very positive attitudes towards tourists and tourism development (Gissurardóttir 2008). Also, it did not meet much opposition from the local fishermen, many of whom saw this as a curious but somewhat, to quote one informant, crazy

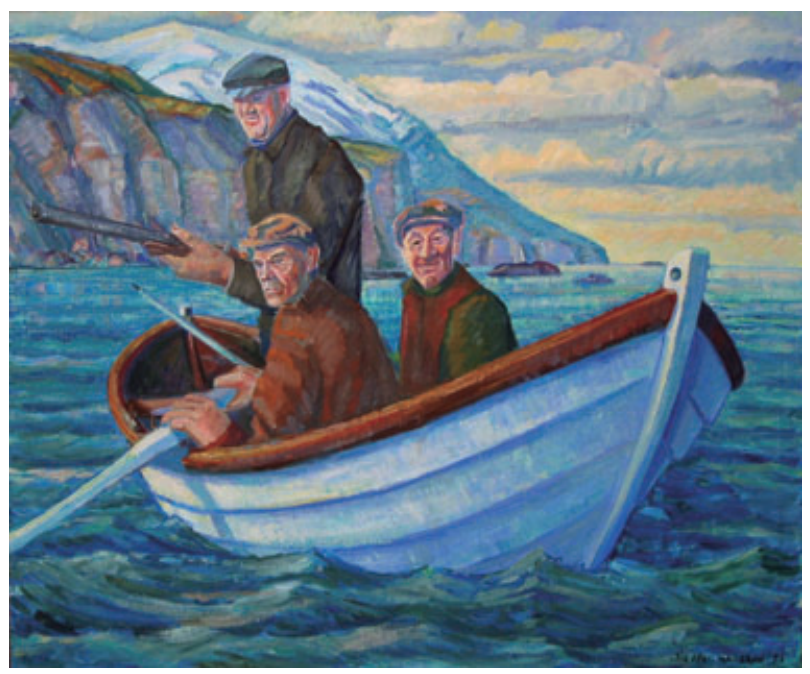

Fig. 3 Hunting seals (Selaróður). Portrait by Húsavík artist Sigurður Hallmarsson. (By permission of the Húsavík Museum House and District Cultural Centre.)

enterprise. Some maintained that there had never been any whales to speak of, neither minke whale nor other types, in Skjálfandi Bay: taking tourists to look at animals who were not there could not be a good and profitable business. Others were worried that the whale-watching boats would interfere with their hunting of marine mammals, especially seals and dolphins, in the bay (Fig. 3).

Dolphins and seals have traditionally been hunted by the fishermen of Húsavík, for their own consumption as well as for shark bait. During my discussions with people in Húsavík, I learned that during the first years of whale watching several incidents occurred in which fishermen had been disturbed during hunting, and tourists had been upset when seals were hunted close to their boat. Instead of leading to increased confrontations and controversies, involving territorial conflict on the now joint hunting and whale-watching grounds, such episodes were addressed through dialogue on land, between spokespersons for the whale-watching operations and individual hunters or fishermen. Fishermen decided to take their hunting further away from the village, and some seem even to have stopped hunting entirely.

Whale watching has also involved considerable development on the foreshore in the harbour area of Húsavík, especially where the company North Sailing has built its facilities to house offices, restaurants and ticket sales, as well as other services for guests (Fig. 4). These developments have mainly occurred in front of the existing baiting sheds, as the fishermen's working facilities or bothies are called in Iceland. Formerly this was an area used by fishermen for their sundry land-based opera- 


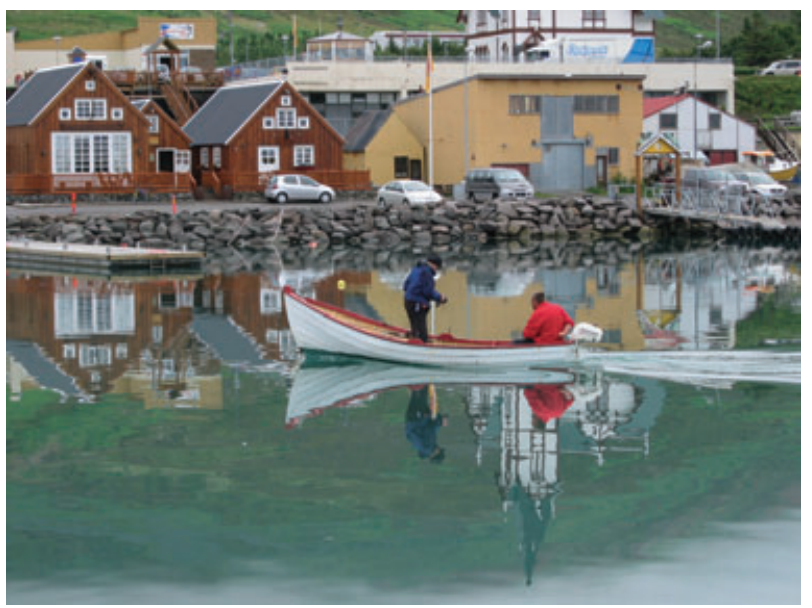

Fig. 4 Húsavík harbour: new driftwood buildings and old baiting sheds in the background. (Photo by N. Einarsson.)

tions, storage and transport of fishing gear. Fishermen complain that the foreshore has become overcrowded, and that tourists, busses, private cars and general traffic associated with the new activities have made life more difficult for them, and that they are having problems moving their fishing gear between boats and sheds. Such complaints are not without foundation, and the increased traffic around the harbour in the prime locations close to the waterfront could lead to conflicts between the new and the traditional activities. Contesting the foreshore is, of course, not an issue unique to Iceland. Tourism-related coastal developments and intrusive planning are a common problem around the world, and in some places it is readily apparent that hotels and swimming pools have been built on spaces once used by fishermen. More usual, however, is that fishing activities, a fringe economy in most countries, unless suitably picturesque, are simply deprived of space or are moved out of sight (see Boissevain \& Selwyn 2004).

In Húsavík, the fact that the new and the old exist in such proximity adds to the authenticity of the stage for whale watching as part and parcel of genuine coastal culture, and thus constitutes a valuable asset. The new buildings also reflect and embody this ideology of whale watching as a natural and embedded extension of local maritime culture. They are architecturally similar to traditional Icelandic timber houses; furthermore, the choice of material-Siberian driftwood gathered on the nearby coastline-reflects an awareness of traditions and environmental consciousness. Through the ages, driftwood has been a major resource for Icelanders, for housing, fences, firewood and various other uses. Authentic wood, used by skilled craftsmen in boats and houses, at sea and ashore, is integral to the image and identity of the whale-watching industry. Wood is often described in animistic terms, as embodying a soul or consciousness, to be treated with respect, and used for economically and culturally meaningful purposes to sustain local livelihoods. To quote one of my informants, "If God had intended boats to be made of plastic he would have created plastic trees." The reference to a divine being stems not from the informant being exceptionally religious, but has more to do with a worldview in which wood as a material is seen as fundamentally natural and authentic, in contrast to the artificial and alien properties of plastic or fibreglass.

In spite of the almost post-modern and new-age attitudes to boats and wood, the ideology of whale watching in Iceland tends to be very much in line with general perceptions of nature in fishing villages, which are for the most part pragmatic and utilitarian, where humans are placed at the centre, and where nature is defined as a potential resource to be appropriated to sustain human livelihoods (see Einarsson 1990, 1993). Whale watching may be welcomed, but the initial reason for this did not have anything to do with idealism concerned with saving whales; instead, it was because the new ecotourism brought opportunities for a constructive and productive use of these sea mammals, contributing to the economic viability of communities, and to the benefit of individuals. However, the success of whale watching in Icelandic communities such as Húsavík has also had the effect of changing the perception of whales as almost vermin to a much more positive one, as whales have now proven their value and therefore right to exist. In the conversation on conservation, this can be a necessary starting point, as a pragmatic approach to conservation issues involving wildlife and resource users should be linked to the social dynamics of resource use, and have an understanding of the cultural context. There are many examples around the world where such an approach has been ignored, resulting in resentment, alienation and unnecessary conflicts between environmentalists and local people (Einarsson 1996, 1999).

The effort to educate foreign and native tourists about whales has been taken seriously in connection with whale watching from Húsavík. The well-designed Húsavík Whale Museum has mounted extensive multilingual exhibits on whaling conservation, whaling history and whale use, and Keiko the Killer Whale, and it includes a new section on whale biology, the marine ecosystem, ocean currents and the threats of pollution in the world's oceans. This impressive museum is led by a pioneer in Icelandic whale watching, who in 2000 was awarded the UN Global 500 award for his conservation work in Iceland.

The museum (based in an old slaughterhouse) and its director and staff have played a major role in Húsavík, as 
well as nationally, in promoting the whale-watching industry, by engaging in dialogue locally and nationally with opponents and supporters. The museum leader, who is a fishing village native himself, has been most active in mediating conflicts that have arisen, and is a tireless participant in persuasion and discussions with fishermen and other villagers about the role of whale watching in community development. Interestingly, the museum has also been able to cooperate with and gain support from local and national political figures alike, as well as major international environmental and whale conservation groups such as WWF, Greenpeace, IFAW and the WDCS. The director is also chair of the Icelandic Whale Watching Association, and acts as their spokesperson.

The Icelandic Whale Watching Association has been in the forefront of criticizing the decision of the Icelandic government in 2003 to resume minke whaling for scientific purposes. The hunting of whales for this research programme ended in the summer of 2007, with a total of 200 animals being taken. The organization has also protested against a decision in autumn 2006 for the resumption of commercial whaling in 2007, allowing a catch quota of nine fin whales and 30 minke whales. The concern of the whale-watching industry, supported by the tourism sector in general, is that resumption of whaling could have a serious negative impact on the future of the new whale-watching businesses, with tourists refraining from visiting Iceland in protest of hunting (Björgvinsson 2007). There are also concerns that whaling will change the behaviour of the minke whales, which have become used to being watched but not harpooned. In areas like Skjálfandi Bay the relatively few animals who stay during the whale-watching season have become tame and easy to get close to, which is of great value for tourists and their experience with the animals. The docile animals, which show interest in boats, accost them and, it appears, view the tourists themselves during an egomorphic encounter (Milton 2005), are called in Icelandic skoðarar, spectators.

\section{Conclusions and discussion}

At the core of my interest in the introduction of whale watching to an Icelandic fishing community, lie questions on sustainability, and on the interactions between and within social and ecological systems. Northern fishing communities are characterized by a very close relationship with the environment on which they base their livelihood. However, this relationship is not deterministic in nature, and human communities, through social agency and social capital, have often shown remarkable adaptability in coping with the forces of change in ecological and social circumstances. As anthropologists, Yvon
Csonka and Peter Swhweitzer have recently argued that, with regards to Arctic societies and cultures, rapid social and cultural change is not something new to Northern communities, although the speed of such change in the 20th century has been unprecedented. According to them:

Arctic societies and cultures are highly adaptable and resilient and thus well-equipped for integrating change. The fact that they integrate modernity should be viewed positively rather than with nostalgia for traditions lost. The concept of traditions should be seen as a dynamic one: traditions do not and should not hinder development.

(Csonka \& Schweitzer 2004:64)

The message from these two social scientists is refreshing, and gives us the opportunity to see Arctic residents in an insightful way, as creative actors with regards to their personal and communal fate, rather than being portrayed as passive and helpless victims of external forces, who are impacted upon and unable to react, staked down by rigid cultural traditions. Here, culture is seen as flexible and creative, rather than static and unchanging, allowing for a variety of representations, permutations and innovative cultural expressions, without this necessarily being interpreted as a certain sign of cultural decay or demise of cultural diversity.

At a recent international meeting on the future of Arctic research, including the human dimension, anthropologist Hugh Beach voiced similar concern, by invoking what could be called the "pizza scenario" of Northern cultural change. His point of view was based on Gregory Bateson's postulate that change in any one relationship occurs in order to keep more primary relationships unchanged. The "pizza illustration" referred to a case in which a traditional Inuit hunter was condemned by cultural purists for supplying his family with pizza, rather than going out on a traditional hunt. Beach's point was that the change to eating pizza occurred because it enabled the hunter to survive (the most primary relationship), with his family, in his community when the hunting was exceptionally bad. Hence, consuming the pizza slice upheld tradition on one level, whereas it was non-traditional on another. Thanks to the availability of pizza, the hunter lived to hunt again. The more general point is that matters of "change" and "tradition" are hierarchically embedded, and are not matters of strict formula outside of the context (Beach, pers. comm. 2005).

Returning to the success of whale watching in an Icelandic community, I argue that important reasons for the positive responses at the local level have to do with the fact that the enterprise was seen as contributing to the local economy and community well-being, as well as being thoroughly integrated into, and presented as part 
of, the community's maritime culture, including the use of salvaged old fishing boats, and the creation of a scene that included other elements of authenticity and local identity. In spite of the radical difference in terms of how the animals are used or appropriated for local livelihoods, the new way of life has not entailed a transformation of the cultural system, but rather a successful adaptation of the new activities into existing patterns of culture and economy. This process has not been entirely without conflicts and controversy, and a key element of the success has been the role of certain skilled individuals working in whale watching who have been engaged locally as culture brokers (see Smith 2001: 275), mediating between hosts and guests, the world of fishermen and the foreign world of whale watching.

Tourism tends to have a somewhat negative reputation in social and environmental science literature, which is quite understandable given the sometimes adverse environmental and social consequences that rapid and careless development of the industry has had in various nooks of the world, not to mention the deep ecological footprint modern mass tourism inflicts on the global climate (see, for example, Smith \& Brent 2001; Boissevain \& Selwyn 2004). One anthropologist has referred to tourists as the sun-tanned destroyers of culture (Crick 1989). However, with regards to the impact of whalewatching tourism in Iceland, I think it might be fairer to say that tourists can also be the salty-faced supporters of conservation and, to an extent, contributors to the viability of coastal communities where marine wildlife tourism has adapted to the local culture and economy (Fig. 5).

This paper is a contribution to a growing trend of interdisciplinary research projects and literature, focussing on the manifold, complex interaction and linkages of social and ecological systems, and institutions, at various scales

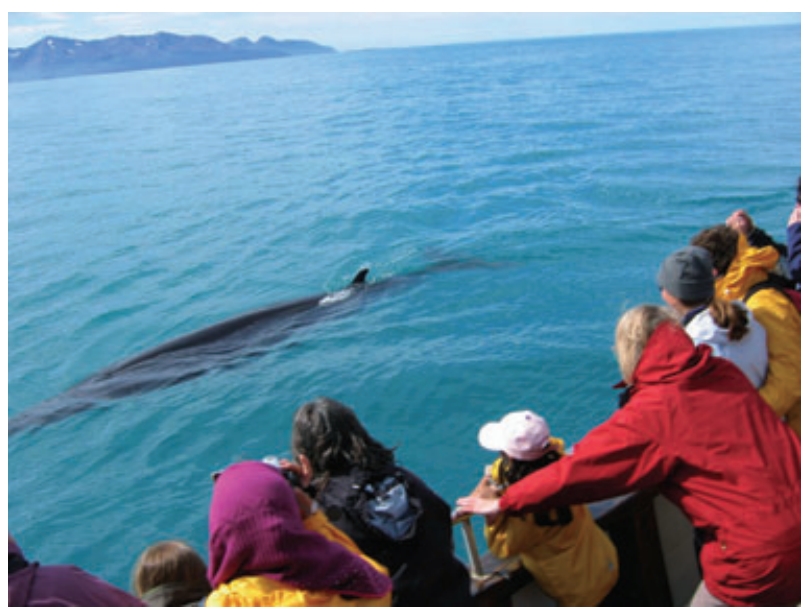

Fig. 5 Tourists and a minke whale. (Photo by N. Einarsson.) and regions (Berkes \& Folke 1998; Berkes et al. 2003; Smit \& Wandel 2006). Key concepts within this comingof-age paradigm have been adaptation and adaptive capacity, resilience, vulnerability, complexity and sensitivity, with an emphasis on one or more of the factors that the concepts refer to, or on the interplay between them. Much of this interdisciplinary research deals with human adaptation and response to climate change. It is my view that an approach that systematically relates human environmental behaviour with socio-ecological systems can be useful, given that the conceptual tools developed for this purpose are contextualized in terms of history, culture and everyday realities of the societies they attempt to analyse and understand, and if the impacts on communities are viewed as cumulative and complex (see Ford et al. 2006; Ford et al. 2007). Otherwise, such studies may be little more than intellectual acrobatics of complex terminology, replacing serious attempts to provide a fuller picture of how people and nature interact. Resilience theory offers one potentially useful point of departure in this endeavour, and within which the results of my study of the introduction of whale watching in Húsavík can be presented as a case study (see Walker et al. 2004). This particular approach is of value, especially as it makes conversation across disciplines easier, and even fruitful, as the goal is to contribute to a more holistic or complete understanding of the dynamism and functions of social and natural systems. Any set of concepts (or even paradigms) that can help us better comprehend the nature of sustainability is worth exploring, even though this means that one may have to leave the safety of one's disciplinary womb.

Changes in the Icelandic fisheries management system when resources became increasingly tied up, resulted in decreased flexibility, and to more responsiveness to external changes in the social and ecological systems that coastal communities occupy. In the case of Húsavík, this predicament did not lead to a chaotic collapse, but rather to reorganization with innovation, and new opportunities. This is a sign of an adaptability that has been defined as "the capacity of actors in the system to influence resilience" (Walker et al. 2004: 1), or, in other words, the ability to manage a socio-ecological system. Adaptation was active on several scales, working at local, national and international levels, and could thus be potentially described as a process of panarchy, involving dynamic interaction across multiple scales (Gunderson $\&$ Holling 2002). In the case we have been reviewing, the community has shown resilience: the capacity to absorb disturbance and to undergo change, while essentially retaining the same structure, identity and function. External influences in global politics and resource regime shifts have acted as triggers, but have not led to the 
total transformation or collapse of the system; these have been adopted through cultural resilience (instead of cultural resistance; see Ris 1993), including the ability to adopt open-mindedness towards alternatives and diversification. The local system has shown a level of transformability that allows continuity through cultural change, where a new landscape has been created with whale watching that is embedded within the distinctive features of an existing landscape. Social factors are crucial within all socio-ecological systems, and, in terms of adaptability, these factors are the determining ones with respect to sustainability and community viability. By studying individual cases of social change in communities, we may learn worthwhile lessons with regards to resilience, adaptability and constructive transformability, and take these further as parables for capacity building and community viability.

\section{Acknowledgements}

This paper is the result of participation in three international research projects: NORSAGA, a project within the European Science Foundation BOREAS programme; SYNICE, a US National Science Foundation supported project; and CAVIAR, an International Polar Year project. I am grateful to Mukulika Banerjee and her colleagues at the University College of London, Department of Anthropology, for comments at a seminar. Thanks for the same are also due to Michael Bravo and the people at the Department of Geography and the Scott Polar Research Institute, University of Cambridge. In Iceland, I wish to thank the people of Húsavík for the opportunity to discuss this paper, at the invitation of the Húsavík Academic Centre, and in Reykjavík at the invitation of the Icelandic Anthropological Society. Special thanks also to my co-workers Jón Haukur Ingimundarson, Joan Nymand Larsen and Lára Ólafsdóttir at the Stefansson Arctic Institute.

\section{References}

Berkes F., Colding J. \& Folke C. 2003. Navigating social-ecological systems: building resilience for complexity and change. Cambridge: Cambridge University Press.

Berkes F. \& Folke C. 1998. Linking social and ecological systems: management practices and social mechanisms for building resilience. Cambridge: Cambridge University Press.

Björgvinsson A. 2007. Whaling undermines whale watching in Iceland. WWF Arctic Bulletin 1.07, 18-19.

Boissevain J. \& Selwyn T. (eds.). 2004. Contesting the foreshore: tourism, society, and politics of the coast. Amsterdam:

Amsterdam University Press.

Brydon A. 1990. Icelandic nationalism and the whaling issue. North Atlantic Studies 2, 185-191.
Caulfield R.A. 2004. Resource governance. In N. Einarsson et al. (eds.): Arctic human development report. Pp. 121-138. Akureyri: Stefansson Arctic Institute.

Crick M. 1989. Representations of international tourism in the social sciences: sun, sex, sights, savings and servility. Annual Review of Anthropology 18, 307-344.

Csonka Y. \& Schweitzer P. 2004. Societies and cultures: change and persistence. In N. Einarsson et al. (eds.): Arctic human development report. Pp. 45-68. Akureyri: Stefansson Arctic Institute.

Duhaime G. 2004. Economic systems. In N. Einarsson et al. (eds.): Arctic human development report. Pp. 69-84. Akureyri: Stefansson Arctic Institute.

Durrenberger E.P. \& Pálsson G. 1996. Introduction. In E.P. Durrenberger \& G. Pálsson (eds.): Images of contemporary Iceland: everyday lives and global contexts. Pp. 1-24. Iowa City: University of Iowa Press.

Central Bank of Iceland 2007. The economy of Iceland. Reykjavík: Central Bank of Iceland.

Einarsson N. 1990. Of seals and souls: changes in the positions of seals in the world view of Icelandic small-scale fishermen. Maritime Anthropological Studies 3(2), 35-48.

Einarsson N. 1993. All animals are equal but some are cetaceans: conservation and culture conflict. In K. Milton (ed.): Environmentalism: the view from anthropology. Pp. 73-84. London: Routledge.

Einarsson N. 1995. Sóun í smábátaútgerð. Eru brennur nauðsynlegar? (Waste in the small-scale fisheries: do we need the bonfires?) Morgunbladið (Fisheries section), 19 April.

Einarsson N. 1996. A sea of images: fishers, whalers and environmentalists. In E.P. Durrenberger \& G. Pálsson (eds.): Images of contemporary Iceland: everyday lives and global contexts. Pp. 46-59. Iowa City: University of Iowa Press.

Einarsson N. 1997. Af hvölum, fiskum og öðru fólki. (Of whales, fish and other people.) In G. Pálsson et al. (eds.): Við og hinir: rannsóknir í mannfroði. (We and the others: research in anthropology.) Pp. 113-125. Reykjavik: University of Iceland Anthropology Institute.

Einarsson N. 1999. Global preservation and the creation of a pest: marine mammals and local response to a moratorium in Arctic Iceland. In D.A. Posey (ed.): Cultural and spiritual values of biodiversity. Pp. 431-433. London: United Nations Environment Programme.

Ford J.D., Pearce T., Smit B., Wandel J., Miskah A., Shappa K., Ittusujurat H. \& Qrunnut K. 2007. Reducing vulnerability to climate change in the Arctic: the case of Nunavut, Canada. Arctic 60, 150-166.

Ford J.D., Smit B. \& Wandel J. 2006. Vulnerability to climate change in the Arctic: a case study from Arctic Bay, Canada. Global Environmental Change 16, 145-160.

Gissurardóttir V.A. 2008. Hugur í heimamönnum: rannsókn á viðhorfum íbúa Húsavíkur og nágrennis til uppbyggingar á ferðapjónustu. (Attitudes to tourism development in Húsavík and vicinity.) BA thesis, Hólar University College. 
Gunderson L.H. \& Holling C.S. (eds.) 2002. Panarchy: understanding transformations in human and natural systems. Washington, DC: Island Press.

Ingold T. 2000. The perception of the environment: essays on livelihood, dwelling and skill. London: Routledge.

Milton K. 2005. Anthropomorphism or egomorphism? The perception of non-human persons by human ones. In J. Knight (ed.): Animals in person: cultural perspectives on human-animal intimacy. Pp. 255-271. Oxford: Berg.

Pálsson G. \& Helgason A. 1996. The politics of production: enclosure, equity and efficiency. In E.P. Durrenberger $\delta$ G. Pálsson G (eds.): Images of contemporary Iceland: everyday lives and global contexts. Pp. 60-86. Iowa City: University of Iowa Press.

Ris M. 1993. Conflicting cultural values: whale tourism in northern Norway. Arctic 46, 156-163.

Sigurjónsson J. 1989. To Icelanders, whales were a godsend. Oceanus Magazine 32, 29-36.

Smit B. \& Wandel J. 2006. Adaptation, adaptive capacity and vulnerability. Global Environmental Change 16, 282-292.
Smith V.L. 2001. The culture brokers. In V.L. Smith \& M. Brent (eds.): Hosts and guests revisited: tourism issues of the 21st century. Pp. 275-282. New York: Cognizant Communication Corporation.

Smith V.L. \& Brent M. (eds.) 2001. Hosts and guests revisited: tourism issues of the 21st century. New York: Cognizant Communication Corporation.

Walker B., Holling C.C., Carpenter S.R. \& Kinzig A. 2004. Resilience, adaptability and transformability in social-ecological systems. Ecology and Society 9(2), article no. 5 .

Wilson B. \& Wilson A. 2006. Whale-watching handbook. A guide to whales, dolphins, and porpoises of the world. St. Paul, MN: Voyageur Press.

World Wide Fund for Nature 2008. Whale watching in the Arctic. Accessed on the internet at http://www.panda.org/ about_wwf/where_we_work/europe/what_we_do/arctic/ what_we_do/species/whales/watching/index.cfm on 20 November 2008. 